\title{
Kontrol Sosial Masyarakat Terhadap Perilaku Mahasiswa Kos-Kosan Air Tawar Barat Padang
}

\author{
Dede Fatma, Isnarmi \\ Prodi Pendidikan Pancasila dan Kewarganegaraan \\ FIS Universitas Negeri Padang \\ E-mail: dedefatma41@gmail.com
}

\begin{abstract}
ABSTRAK
Masyarakat melakukan kontrol sosial kepada mahasiswa, agar mereka berperilaku baik dan mentaati peraturan yang di buat oleh pemilik kos. Penelitian ini bertujuan untuk mengetahui kontrol sosial masyarakat terhadap perilaku mahasiswa kos-kosan. Agar mahasiswa mematuhi peraturan yang telah di buat oleh pemilik kos dan RT setempat dan mengetahui kendala dan upaya masyarakat dalam mengatasi perilaku mahasiswa sehingga mahasiswa mematuhi peraturan dikos maupun di lingkungan masyarakat. Penelitian ini merupakan penelitian kualitatif deskriptif. Subyek dari penelitian ini berjumlah 17 orang yang terdiri dari RT Jl. Gajah masyarakat, pemilik kos dan penghuni kos (mahasiswa) yang dapat membantu penelitian dalam permasalahan yang peneliti bahas. Dalam pelaksanaan kontrol sosial dilingkungan masyarakat tidak ada. Adapun kendala dari masyarakat terhadap pelaksanaan kontrol sosial masyarakat sekitar kurangnya kepedulian sosial/kerja sama pemilik kos dan masyarakat terhadap pengawasan agar mahasiwa mentaati peraturan. Lalu upaya yang dilakukan oleh RT dan pemilik kos membuat peraturan dan sanksi yang tegas bagi mahasiswa yang melanggar peraturan tersebut. Maka dari itu perlu adanya penerapan kontrol sosial masyarakat terhadap perilaku mahasiswa kos, agar tidak berperilaku menyimpang.
\end{abstract}

Kata Kunci: kontrol sosial, peraturan kos, perilaku mahasiswa

\section{ABSTRACT}

The community exercises social control on students, so that they behave well and obey the rules made by the boarding house owner. This study aims to determine the social control of the community on the behavior of students in boarding houses. So that students comply with the rules that have been made by the owner of the boarding house and the local RT and knowing the obstacles and efforts of the community in overcoming student behavior so that students comply with the rules of the boarding school and in the community. This research is a descriptive qualitative research. The subjects of this study were 17 people consisting of RT in Gajah street, boarding house owners and boarding house residents (students) who can help research on the problems that the researchers discuss. There is no social control in the community. As for the obstacles from the community to the implementation of community social control around the lack of social care / cooperation between boarding houses and the 
community towards supervision so that students obey the regulations. Then the efforts made by the RT and boarding house owners made strict rules and sanctions for students who violated these rules. Therefore, it is necessary to implement social control over the behavior of boarding school students, so as not to behave deviantly.

Keywords: social control, boarding rules, student behavior

(c) (†) (2) This work is licensed under the Creative Commons Attribution-ShareAlike 4.0 International License. EY

\section{PENDAHULUAN}

Mesyarakat melakukan kontrol sosial kepada mahasiswa agar mereka berperilaku baik dan mentaati peraturan yang dibuat oleh pemilik kos. Menurut (Gunawan, 2017) Kontrol sosial masyarakat sebagai suatu pengendalian masyarakat, yang dilakukan untuk mencegah terjadinya pelanggaran didalam perspektif masyarakat atau seseorang diarahkan, tidak melakukan pelanggaran.

Pembahasan mengenai pengendalian sosial sebagai proses, baik direncanakan maupun tidak di rencanakan harus bersifat mendidik, mengajak, bahkan memaksa wargawarga masyarakat agar mematuhi kaidah dan nilai-nilai sosial yang berlaku. Menurut (Putra, 2018) menjelaskan dalam bentuk kontrol atau kendali dijadikan untuk mengatur berbagai perilaku atau tingkah laku anggota kelompok sosial supaya tingkah laku para anggota tersebut ada pada batasan-batasan tingkah komformis. Artinya tingkah laku manusia hendaknya dibatasi oleh aturan-aturan, sehingga manusia tersebut dapat terkontrol dalam bertindak serta mengetahui mana yang boleh dilakukan dan perbuatan yang tidak boleh dilakukan.
Hal ini tentu dalam bentuk perintah serta larangan. Menurut (Narwoko \& Suwanto, 2015)ada empat unsur didalam kontrol sosial internal, yaitu Attachement (kasih sanyang) dimana sebagai sumber kekuatan yang muncul dari hasil sosialisasi didalam kelompok sehingga individu mempunyai komitmen untuk patuh terhadap aturan. Commitment (tanggung jawab) pada aturan dapat memberikan kerangka kesadaran yang berupa kesadaran pentingnya melaksanakan aturan yang sudah di buat. Involvement (keterlibatan atau partisipasi) didalam ketentuan yang telah ditetapkan oleh masyarakat, intensitas keterlibatan seseorang terhadap aktivitas normatif konvensional dengan sendirinya akan mengurangi peluang seseorang untuk melakukan tindakan melanggar Hukum, dan Believe (kepercayaan/ keyakinan) pada norma sosial atau aturan masyarakat pada akhirnya akan bertanam kuat padadiri seseorang.

Penelitian oleh (Hanifah, 2013) menunjukan bahwasannya Kontrol sosial dari orang tua pada anak sangatlah penting bagi remaja untuk mengarahkan, memberikan nasehat, memberikan pujian atau hukuman atas perilaku remaja itu sendiri. Dimana terdapat $25,63 \%$ orang tua 
tidak pernah menerapkannya $23,10 \%$ orang tua jarang terdapat $26,55 \%$ orang tua yang sering menerapkannya yang selalu mengontrol aktivtas remaja. Dalam penelitian tersebut melakukan kontrol atau pengendalian sosial dari oarang tua agar anak tersebut berperilaku baik dilingkungan. Sedangkan Menurut penelitian (Alias, Fatmawati, \& Mochtaria, 2013)Kontrol sosial ustazd yang telah dilakukan dalam mengatasi perilaku menyimpangan sosial remaja dengan pendekatan preventif yaitu menasehati orang tua agar menciptakan keluarga yang harmonis, terbuka dan jauh dari akhlak yang tidak baik.Tindakan ini lebih mendekatkan hubungan orang tua dengan anaknya. Dimana perlu adanya kontrol sosial untuk anak dan remaja agar berperilaku yang baik dan tidak melewati batasannya/ berperilaku menyimpang.

Menurut penelitian (Hamzah, 2015)yang berjudul peran kontrol sosial dalam pengendalian perilaku mahasiswa kos universitas mulawarma semarang. Dari hasil penelitian tersebut adanya kontrol sosial menunjukkan bahwa secara umum perilakumahasiswa kos di sekitar kampus Universitas Mulawarman Samarinda masihdalam batas-batas kewajaran karena tidak mengganggu keamanan dan ketertibanwarga di lingkungan tersebut. Beberapa perilaku mahasiswa kos yang dapatmengganggu lingkungan antara lain membuat keributan, membuang sampahsembarangan, minumminuman keras, narkoba, dan sex bebas. Dengan adanya penelitian tentang kontrol sosial ini, bisa mengetahui perlunya sekali adanya kontrol sosial masyrakat di lingkungan sekitar.

Perbedaan dan persamaan, dari penelitian yang telah dilakukan seperti kontrol orang tua kepada anak agar orang tua mengarahkan dan memberikan nasehat, memberikan pujian atau hukuman apabila berperilaku tidak sesuai. Adanya persamaan hasil penelitain yang telah diteliti oleh hamzah mengenai perilaku mahasiswa dikarenakan masih terdapat mahasiswa kos yang dapat mengganggu lingkungan seperti membuat keributan, membuang sampah sembarangan, minumminuman keras, narkoba, dan sex bebas. Dalam penelitian ini, peneliti juga meneliti tentang perilaku mahasiswa yang melanggar peraturan seperti, pulang larut malam, tidak menjaga kebersihan, masih terdapat mahasiswa/i yang masih berkomunikasi dengan lawan jenis di depan teras pada batas waktu yang talah di tentukan pemilik kos.

Peneliti melakukan observasi awal dalam Kehidupan anak kos, memang dirasakan suatu perubahan yang besar, biasanya di rumah mereka selalu diperhatikan dan diawasi oleh kedua orang tua mereka. Namun setelah mereka tinggal berjauhan dari pandangan dan pengawasan orang tua, mereka merasa lebih bebas dalam bergaul baik itu laki-laki ataupun perempuan.

Tidak heran sering kali kita jumpai ditengah tengah masyarakat anak kos-kosan bebas mengunjungi kos laki-laki ataupun perempuan tanpa tau batasan waktu, sehingga menjadi kebiasaan. Masih terdapat mahasiswa pulang larut malam, sehingga sering berada diluar dan 
berkomunikasi dengan lawan jenis. Kurangnya pantauan RT setempat dilingkungan masyarakat kos- kosan serta masih kurangnya kepedulian pemilik kos terhadap mahasiswa yang menyewa rumah kos dan kurangnya interaksi mahasiswa dengan masyarakat berakibatbanyaknya terdapat mahasiswa yang melanggar peraturan yang telah di buat oleh pemilik kos. Maka dari itu perluadanya kontrol sosial masyarakat terhadap perilaku mahaiswa dilingkungan kos.

Masyarakat melakukan kontrol sosial agar perilaku mahasiswa lebih terawasi oleh masyarakat sekitar, dengan adanya pengendalian sosial tersebut, mahasiswa tidak berperilaku seenaknya, dan perlu adanya kerja sama pemilik kos dan masyarakat dalam menerapkan peraturan yang tegas beserta sanksi bagi yang melanggar. Sehingga dengan adanya peraturan yang tegas mahasiswa menataati peraturan dari RT dan pemilik kos. .

Penelitian ini bertujuan agar pengendalian sosial dimasyarakat terhadap perilaku mahasiswa koskosan yang berada di Air Tawar Barat Padang khusunya di Jl. Gajah yang bedekatan dengan kampus UNP, yakni agar mahasiswa tersebut lebih mentaati peraturan yang telah dibuat oleh pemilik kos dengan cara tidak pulang larut malam dan duduk-duduk di depan teras kos berduaan melewati batas waktu bertamu pada malam hari, dan saling menjaga kebersihan lingkungan kos maupun sekitarnya. Maka dari itu dengan adanya kontrol sosial masyarakat terhadap perilaku mahasiswa, masyarakat jadi lebih peduli terhadap lingkungan, dengan adanya kerja sama antar RT, masyarakat dan pemilik kos dalam menjaga lingkungan tetap aman dan berperilaku baik, maka dari itu RT dan masyarakat membuat peraturan, dan apa bila terdapat mahasiswa kos melanggar peraturan tersebut akan dikenakan sanksi/hukuman.

\section{METODE PENELITIAN}

\begin{tabular}{lrr}
\multicolumn{2}{c}{ Penelitian ini } & merupakan \\
penelitian kualitatif & $\begin{array}{r}\text { dengan } \\
\text { menggunakan metode }\end{array}$ \\
karena penelitian ini berusaha untuk \\
mendiskripsikan gambaran yang \\
terjadi pada
\end{tabular} penelitian.Penelitian ini berlokasi di Kelurahan Air Tawar Barat padang Jl. Gajah kecamatan Padang Utara. Teknik pemilihan informan yang digunakan peneliti yaitu purposive sampling, mampu menetapkan kriteria dan adanya pertimbangan tertentu sehingga dalam penelitian ini yang diperoleh sesuai dengan penelitian yang dilakukan oleh peneliti. Dalam penelitian ini informan berjumlah17 informan yang terdiri dari RT, masyarakat dan penghuni kos yang dianggap dapat membantu peneliti dalam permasalahan penelitian. Dan hasil penelitian ini diuji dengan teknik triangulasi yaitu membandingkan data hasil pengamatan dengan data hasil wawancara, dan membandingkan apa yang dikatakan orang tentang situasi penelitian.

\section{HASIL DAN PEMBAHASAN}

Berdasarkan hasil penelitian yang ditemukan dilapangan dalam pelaksanaan kontrol sosial masyarakat terhadap perilaku mahasiswa kos tidak ada kontrol sosial atau pengawasan dilingkungan kos-kosan tersebut, dimana dilingkungan koskosan tersebut masih terdapat 
mahasiswa yang melanggar peraturan yang telah dibuat oleh pemilik kos maupun RT setempat. Dalam temuan peneliti bahwasannya di setiap koskosan di Jl. Gajah terdapat peraturan tertulis dan tidak tertulis (lisan), peraturan tersebut agar mahasiswa mentaati peraturan dan berperilaku baik di lingkungan masyarakat.

Tabel 1: Data kos-kosan yang memiliki peraturan di RT Jl. Gajah kelurahan Air Tawar Barat pada tahun 2019

Sumber: olahan penelitian
\begin{tabular}{|l|l|l|l|c|c|}
\hline \multirow{2}{*}{ No } & RT & \multicolumn{2}{|c|}{ Peraturan kos } & \multicolumn{2}{c|}{ Peraturan Tertulis } \\
\cline { 3 - 6 } & & Ada & Tidak ada & Ada & Tidak ada \\
\hline 1 & 1 & 21 & - & 9 & 12 \\
\hline 2 & 2 & 23 & - & 7 & 16 \\
\hline 3 & 3 & 18 & - & 7 & 11 \\
\hline 4 & 4 & 27 & - & 8 & 19 \\
\hline 5 & 5 & 25 & - & 10 & 15 \\
\hline 6 & 6 & 27 & - & 6 & 21 \\
\hline Jumlah & 141 & & 47 & 94 \\
\hline
\end{tabular}

Dalam menerapkan peraturan terhadap mahasiswa kos, terdapat peraturan tertulis dan tidak tertulis, akan tetapi kebanyakan peraturan tersebut disampaikan secara lisan kepada mahasiswa kos. Dan hasil pengamatan penulis selanjutnya dapat dilihat bahwa ada banyak rumah kos di kelurahan Air Tawar Barat Padang yang berdiri dilingkungan tersebut. Bahwasannya pemilik kos tidak tinggal dirumah tersebut sehingga memcul hal-hal yang tidak lumrah bagi masyarakat seperti bertamu sembarangan dan masuk kerumah kos tanpa melihat batas waktu bertamu,dan masih saja banyak mahasiwa/i yang melanggar peraturan yang lain seperti pulang larut malam dan berduaan di depan teras kos pada waktu magrib atau bertamu hingga malam hari serta juga masih saja terdapat mahasiswa yang tidak menjaga kebersihan lingkungan kos. Adapun pelaksanaan kontrol sosial di lingkungan masyarakat sebagai berikut:

Tabel. 2: Data kontrol sosial terhadap perilaku mahasiswa

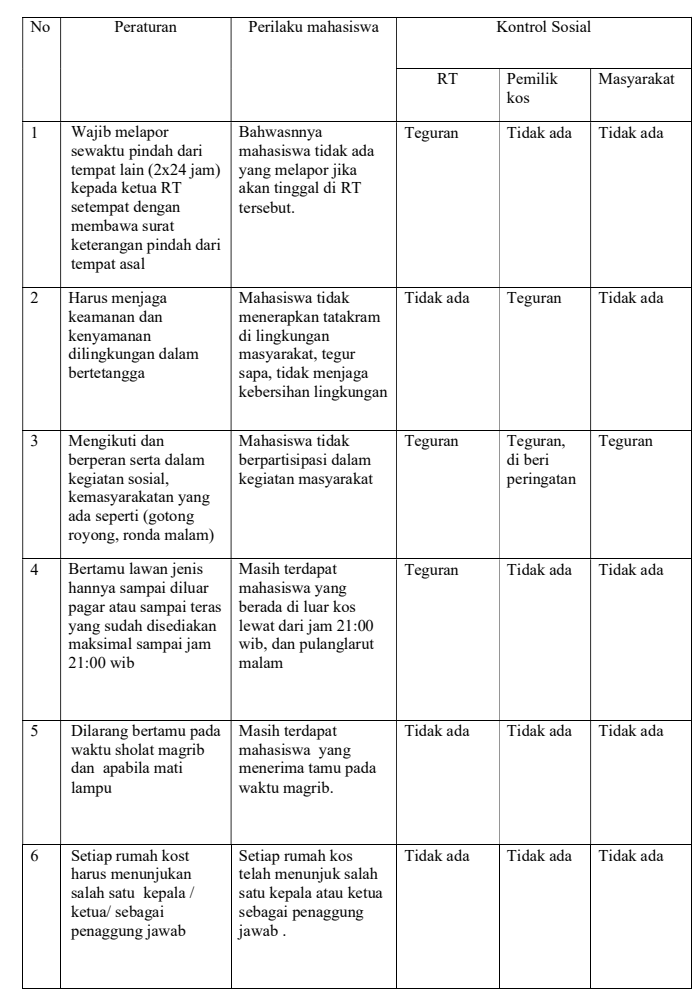

Sumber: olahan penelitian

Berdasarkan tabel diatas dalam peraturan yang ada, bahwasannya peraturan tersebut tidak ada kontrol sosial di lingkungan masyarakat. Dikarenakan kurangnya kepedulian sosial di lingkunngan di Jl. Gajah, dimana masyarakat disana memiliki sifat individualism. 
Tabel. 3 : Upaya Kontrol Sosial masyarakat

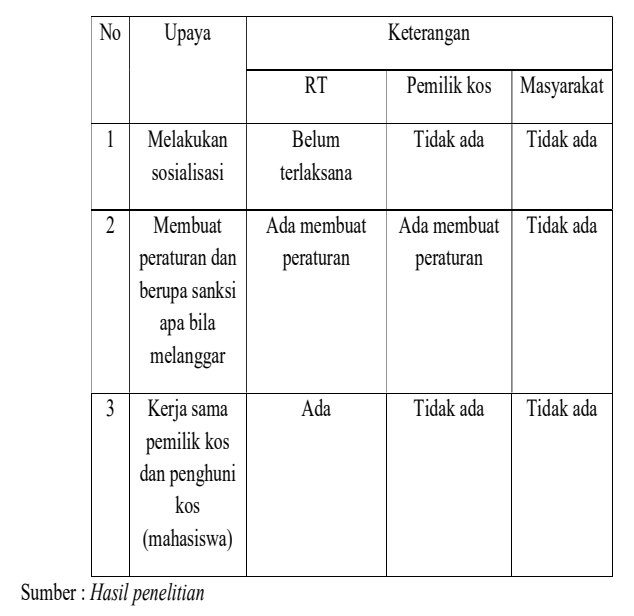

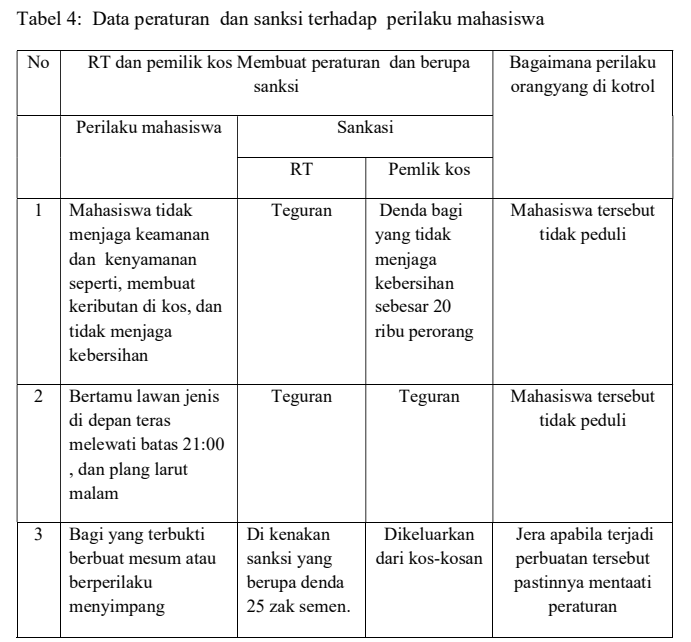

Berdasarkan tabel diatas Dapat disimpulkan bahwa, upaya yang dilakukan dari RT, pemilik kos dan masyarakat seperti melakukan sosialisasi RT setempat tentang peraturan-peraturan yang ada dilingkungan belum terlaksana sepenuhnya, adapun peraturan/ sanksi yang dibuat oleh pemilik kos, tidak di terapkan oleh penghuni kos. Untuk kerja sama antara pemilik kos, mahasasiswa (penghuni kos) dan masyarakat dalam pengawasan perilaku mahasiswa belum ada. Namun di lingkungan masyarakat sudah menerapkan kerja sama seperti gotong royong untuk menjaga kebersihan lingkungan kos-kosan.
Pembahasan hasil penelitian ini, peneliti memperoleh penjelasan tentang kontrol sosial masyarakat Terhadap Mahasiswa Kos-kosan Air Tawar Barat Padang. Terkait penelitian yang dilakukan, tentang pelaksanaan kontrol sosial masyarakat terhadap perilaku mhasiswa kos-kosan, serta kendala yang dialami dalam pelaksanaan kontrol sosial dan mengetahui upaya yang dilakukan dalam pelaksanaan kontrol sosial. Temuan tersebut akan dipaparkan sebagai berikut:

\section{Pelaksanaan kontrol sosial masyarakat terhadap perilaku mahasiswa kos-kosan}

Masyarakat merupakan sebuah sistem sosial dimana bagian yang ada didalamnya saling berhubungan antara satu dengan lainnya dan menjadikan bagian-bagian tersebut menjadi kesatuan yang terpadu. Menurut (Tejokusumo, 2014) masyarakat adalah kelompok kehidupan manusia yang hidup bersama-sama. pelaksanaan kontrol sosial dilingkungan masyaraka agar lingkungan aman.

Kontrol masyarakat terhadap lingkungan agar menerapkan perilaku yang baik dan mematuhi peraturan. Kontrol sosial menurut (Putra, 2018) kontrol atau kendali dijadikan untuk mengatur berbagai perilaku atau tingkah laku anggota kelompok sosial supaya tingkah laku para anggota tersebut ada pada batasan-batasan tingkah komformis. Artinya tingkah laku manusia hendaknya di batasi oleh aturan-aturan sehingga manusia tersebut dapat mengetahui mana yang boleh dilakukan dan perbuatan yang tidak boleh dilakukan. Adapun pelaksanaan kontrol sosial masyarakat 
terhadap perilaku mahasiswa koskosan Air Tawar Barat Padang khusunya di Jl. Gajah dengan melaksanakan ronda malam demi kemanan dan kenyamanan.

Dalam melaksanakan kontrol sosial di masyarakat, menurut (Aditia, Hamiyati, \& Rusiilanti, 2016) perlu adanya kepedulian sosial, nilai penting yang harus dimiliki setiap orang karena terkait dengan nilai kejujuran, kasih sayang, rendah hati, kebaikan dan sikap selalu ingin membantu orang lain. Dan kepedulian sosial tidak terlepas dari kesadaran sosial.

kepedulian sosial pada dasarnya merupakan salah satu dari sekian banyak nilai yang di karuniai sifat yang bertuju pada kepentingan sendiri (sifat individual), dan sifat yang tertuju pada kepentingan oranglain, masyarat umun dan negara (sifat social). Kedua sifat ini saling berkuasa oleh karenanya sifat ini perlu dikendalikan dan dikembangkan secara serasi agar tidak timbul penyimpangan perilaku. Menurut (Soenarko, 2015)kepedulian adalah perihal sangat peduli, sikap mengindahkan sikap memperhatikan. Ketidak pedulian sama halnya mati rasa. Kepedulian sosial adalah minat atau ketertarikan untuk membantu orang lain. Karena peduli itu tidak hanya tau tentang sesuatu yang salah atau benar tetapi ada kemauan untuk melakukan sekecil apapun.

Namun temuan kontrol sosial di dalam masyarakat terhadap perilaku mahasiswa kos-kosan di Air Tawara Barat Jl. Gajah, tidak ada. Dikarenannya tidak telaksanan kontrol kurangnya kepedulian sosial di dalam masyarakat, dimana masyarakat tersebut tidak peduli terhadap lingkungan sekitar, bukan mayarakat saja yang tidak peduli, pemik kos juga tidak menerapkan kontrol terhadap rumah kos yang di sewannya, seharusnya pemilik kos lebih mengontrol rumah kos, dan perilaku mahasiswa dan menerapkan peraturandan sanksi yang tegas bagi yang melanggar peraturan tersebut. Maka perlunya kepedulian sosial di dalam lingkungan masyarakat agar lingkungan tersebut aman, dan masyarakat mentaati peraturan.

Kendala dalam pelaksanaan kontrol sosial dimasyarakat terhadap perilaku mahasiswa kos-kosan

Dalam pelaksanaan kontrol sosial masyarakat terhadap perilaku mahasiswa kos-kosan Air tawar barat padang. pada pelaksanaannya masih terdapat beberapa kendala, adapun kendala tersebut yakni sebagai berikut:

a. Faktor dari masyarakat

Dalam pelaksanaan Kontrol Sosial terdapat kendala seperti kurangnya pengawasan dilingkungan masyarakat. Menurut (Handoyo, Astuti, Iswari, Alimi, \& Mustofa, 2015) ia mengatakan Masyarakat adalah kelompok kehidupan manusia yang hidup bersama-sama diwilayah dan berbagai iklim, kesenangan maupun kesedihan.

Dalam kehidupan bermasayarakat interaksi merupakan suatu poin penting, namun dikarenakan tidak adanya interaksi yang baik antar masyarakat dan mahasiswa sehingga menimbulkan penilaian yang buruk terhadap mahasiswa, yang mengakibatkan hilangnya kepedulian terhadap lingkungan sekitar.

Pentingnya kepedulian sosial di lingkungan 
masyarakat menurut (Marwing, 2016)kepedulisn sosial sebuah " rasa bersosial" atau " rasa berkomunitas" yang berarti rasa persatuan dengan semua umat manusia. Kepedulian sosial sebagai kerja sama dengan orang lain demi kemajuan sosial dan tidak tertuju pada keunggulan pribadi semata. Adapun beberapa dampak yang ditimbulkan tidakadanya kepedulian sosial seperti kurangnya pengawasan terhadap mahasiswa di kos-kosan yang berakibat peraturan kos tidak dipatuhi. Hal inilah yang menjadi pemicu terjadinya perilaku menyimpang di lingkungan tersebut.

\section{b. Faktor dari mahasiswa}

Masyarakat melakukan kontrol sosial terhadap perilaku mahasiswa, factor utama yang paling penting ialah kesadaran mahasiswa itu sendiri, yakni patuh pada aturan yang sudah diterapkan. Menurut (Wulan \& Abdullah, 2014) mahasiswa adalah peserta didik pada jenjang perguruan tinggi dan berperan tinggi dalam mewujudkan cita cita. Jadi sebagai mahasiswa seharusnya paham, tau mana yang boleh dilakukan dan mana yang tidak boleh dilakukan, serta menerapkan etika yang baik dan menjalin komunikasi dengan masyarakat sekitar agar masyarakat peduli terhadap lingkungannya.

Pelaksanaan kontrol sosial masyarakat dilingkungan kos Jl. Gajah tidak terlaksana, dikarenakan masih saja terdapat kos yang tidak menjaga kersihan. Dikarenakan kurangnya kontrol dari pemilikkos dan kurangnya penekanan terhadap peraturan kos serta hubungan yang kurang baik dengan masyarakat, sehingga menyebabkan masyarakat tidak peduli/ tidak mau menegur mahasiswa jika kos tersebut kontor/ tidak menjaga kebersihan, serta dari mahasiswa itu sendiri tidak adanya kesadaran untuk menjaga kebersihan lingkungan kos.

Seharusnya mahasiswa tersebut sadar agar peduli pada lingkungan, supaya lingkungan tersebut bersih tidak ada sampah yang berserak/bertumpuk di depan kos. Dan pentingnya pengawasan pemilik kos terhadap kos-kosan tersebut sangat diperlukan agar mahasiswa yang tinggal dikos mau ikut berpartisipasi dalam menjaga kebersihan lingkungan sekitar dan mau mentaati peraturan yang telah di buat oleh pemilikkos, dengan cara tidak pulang larut malam dan tidak berkomunikasi dengan lawan jenis di depan kos pada saat malam hari yang dapat menyebabkan keresahan masyarakat sekitar.

Dengan adanya penekanan pada peraturan terhadap penghuni kos, serta kerja sama masyarakat, mahasiswa dan pemilik kos akan memberikan dampak yang baik, seperti terciptanya lingkungan yang aman dan nyaman.

\section{Upaya yang dilakukan masyarakat dalam pelaksanaan kontrol sosial}

a. Upaya masyarakat

Masyarakat melakukan sosialisasi kepada mahasiswa tentang peraturan yang diterapkan lingkungan masyarakat. Menurut Abdul Syani yang dikutip oleh (Anwar, 2018) sosialisasi adalah proses belajar yang dilakukan individu untuk membuat atau bertingah laku berdasarkan patokan yang terdapat dan diakui dalam masyarakat sekitarnya. Sosialisati sangat diperlukan dimana RT serta tokoh masyarakat membuat 
Journal of Civic Education (ISSN: 2622-237X)

Volume 3 No. 32020

peraturan yang tegas dah harus dipatuhi bagi masyarakatnya yang tinggal dilingkungan tersebut, tanpa terkecuali mahasiswa yang tinggal di lingkungan tersebut.

\section{b. Upaya pemilik kos}

Pemilik kos menerapkan peraturan untuk penghuni kos agar mematuhi peraturan tersebut. Jika melanggar akan diberi sanksi sesuai yang telah disepakati bersama. Pemilik kos berkerja sama dengan masyarakat untuk memberi pengwasan terhadap perilaku mahasiswa dilingkungan. Agar pemilik kos dapat mengingatkan mahasiswa yang pindah ataupun tinggal di wilayah tersebut wajib mengutamakan melapor kepada RT setempat.

Dalam rangka menjaga ketentraman lingkungan bagi daerah yang kebanyakan mengelola rumah kos agar lebih terawasi, di adakanlah razia/ patroli dilingkungan kos tersebut agar mahasiswa/ penghuni kos tidak melakukan perilaku menyimpang, seperti tidak adanya lagi yang pulang malam ataupun masih duduk didepan kos lewat jam 21:00 bersama lawan jenis di malam hari. Mahasiswa harus mematuhi peraturan dan menerapkan tata krama yang baik dilingkungan masyarakat agar masyarakat tersebut peduli akan lingkungan sekitarnya. Pemilik kos harus membuat peraturan dan sanksi yang tegas untuk yang tinggal di koskosan

\section{KESIMPULAN}

Pelaksanaan kontrol sosial di dalam masyarakat terhadap perilaku mahasiswa kos-kosan di Air Tawara Barat Jl. Gajah, tidak ada. Dikarenannya tidak telaksanan kontrol kurangnya kepedulian sosial dan tidak mentaati peraturan didalam masyarakat, dimana masyarakat tersebut tidak peduli terhadap lingkungan sekitar, seharusnya pemilik kos lebih mengontrol rumah kos, dan perilaku mahasiswa dan menerapkan peraturandan sanksi yang tegas bagi yang melanggar peraturan tersebut.

Kendala dalam pelaksanaan
kontrol sosial perilakumahasiswa kos, dari faktor masyarakat dan mahasiswa di karenakan tidak adanya interaksi yang baik antar masyarakat dan mahasiswa sehingga menimbulkan penilaian yang buruk terhadap mahasiswa, yang mengakibatkan hilangnya kepedulian terhadap lingkungan sekitar.

Upaya yang dilakukan masyarakat dalam pelaksanaan kontrol sosial. masyarakat membuat peraturan yang tegas dah harus dipatuhi bagi masyarakatnya yang tinggal dilingkungan tersebut, tanpa terkecuali mahasiswa yang tinggal. Adapun dari pemilik kos berkerja sama dengan masyarakat untuk memberi pengwasan terhadap perilaku mahasiswa dilingkungan. Agar pemilik kos dapat mengingatkan mahasiswa yang pindah ataupun tinggal di wilayah tersebut wajib mengutamakan melapor kepada RT dan memberi peraturan yang tegas bagi yang tinggal dilingkungan tersebut.

\section{DAFTAR PUSTAKA}

Aditia, H. R., Hamiyati, \& Rusiilanti. (2016). Hubungan Pola Asuh Orang Tuadengan Kepedulian Sosial Remaja. Jurnal Kesejahteraan Keluarga Dan Pendidikan, 03(02). 
Alias, M., Fatmawati, \& Mochtaria. (2013). Kontrol Sosial Tokoh Masyarakat ( Ustad) Dalam Mengetasi Perilaku Remaja di Desa Limbung Kecamatan Singai Raya Kabupaten Kubu Raya. Jurnal Tesis PMIS.

Anwar. (2018). Paradigma Sosialisasi dan Konstribusinya Terhadap Pengembangan Jiwa Beragama Anak. Kesejahteraan Keluarga Dan Pendidikan, 11(1), 65-78.

Hamzah, M. (2015). Peran kontrol sosial dalam penegendalian perilaku mahasiswa kos sekitar kampus universitasn mulawarman samarinda. E. Joernal Sosiatri, 3(2), 124-137.

Handoyo, E., Astuti, T. M. P., Iswari, R., Alimi, Y., \& Mustofa, M. S. (2015). Studi Masyarakat Indonesia. Yogyakarta: Ombak.

Hanifah, F. (2013). Hubungan Kontrol Sosial Orang Tua Dengan Perilaku Seks Pranikah Remaja Kelurahan Batang Arau Kecamatan Padang Selatan. SPEKTRUMPLS, 1(2), 1-14.

Marwing. (2016). Kritik Kepedulian Sosial Adler Dan Ikhlas Terhadap Perilaku Pro Sosial Manusia Modern. Kontemperasi, 4(2), 1-24.

Narwoko, J. D., \& Suwanto, B. (2015). Sosiologi Teks Penantar dan Terapan. Jakarta: Predanamedia Group.

Putra, I. B. S. (2018). Sosial Control : Sifat dan Sanksi Sebagai Sarana Kontrol Sosial. Jurnal VYAVAHARADUTA, XIII(1), 21-32.

Soenarko, M. (2015). Peningkatan Nilai Kepedulian Sosial Melalui Modifikasi Model Pembelajaran Konsiderasi Pada Mahasiswa Tingkat 1 Program Studi PGSD FKIP UNIVERSITAS NUANTARA PGRI KEDIRI. (6),
2355-7621.

Tejokusumo, B. (2014). Dinamika Masyarakat Sebagai Sumber Belajar Ilmu Pengetahuan Sosial. Geoedukasi, 3(2), 38-43.

Wulan, D. A. N., \& Abdullah, S. M. (2014). Prokratinasi Akademik Dalam Penyelesaian Skripsi. Jurnal Sosio-Humaniora, 5(1), 65-78. 